\section{REDWINGED BLACKBIRD WITH WHITE WING PATCHES SEEN AT REGINA}

On June 4, 1960, the Regina Bird Group visiting a marshy s'ough five miles west of the city saw a Redwing with conspicuous white feathers in both wings. These showed as narrow white stripes when the wings were closed but were very conspicuous in flight. About six of the large outer feathers in each wing were pure white and there was a third smaller patch of white feathers closer to the body on the rear of the left wing. The white patches did not affect the red shoulder patches which seemed particularly bright.

There were other Redwings in the area but the centre of the marsh was mainly held by Yellow-headed Blackbirds. The conspicuous Redwing with the white wings was displaying, isolated from other Redwings, in a corner of the marsh close to the road and he frequently perched on a lone post on the edge of the territory. He was observed in this spot again on June 5, 6, and 7 . One or two females could also be seen in the territory.

The bird was still in the area on the same post on fuly 29. He was also seen on telephone wircs among a group of female and normal-plumaged juvenile Redwings, but it is nut definitely known whether he was successful in raising a family.-G.F.L.

\section{ROUGH-WINGED SWALLOWS IN ARM RIVER VALLEY}

P. Lawrence Beckie of Bladworth reports that on May 29, 1960, he saw his first Rough-winged Swallow near a bridge along the Arm River near Bladworth. He went to check it for nesting on May 31, but the swallow was no longer there. Rough-winged Swallows (3) were also ubserved at another location along the Arm River, near Findlater, by Margaret Belcher on the same day that Iuawrence Beckie made his observation. Almost a week earlier (May 23) George Ledingham noted three Rough-winged Swallows flying over the Qu'Appelle Valley at Lumsden, and three were seen again in the same location on May 29 by Margaret Belcher. However, Roughwinged Swallows were not noted there by the Bird Group, June 4.

\section{LAZULI BUNTING AT FORT SAN}

by E. M. Callin, Fort San

On July 12, 1960, I hiad the good fortune to sce my first Lazuli Bunting (Passerina amoena). A strange song had been heard near our house at noon on the previous day but upon being approached the singer disappeared and became silent. At 6.50 the next morning the song was heard again in the same area and twice during the next half hour I was re-. warded by brief observations of this beautiful stranger before the House Sparrows and next a Catbird took exception to its presence and rrove it away. Undoubtedly the bird, rrobably a lone male, soon moved on, for up to the date of writing (July 18) it has not been seen or heard again.

The breeding range of the Lazuli Bunting, according to the A.O.U. Check-List of North American Birds (5th Edition). includes southern Saskatchewan. However, we usually associate this species with the mountains and foothills of southern B.C. and Alberta, and there are not many Saskatchewan records. Mr. Fred Bard reviewed Saskatchewan records in the Blue Jay when Nancy Dunn reported a Lazuli Bunting nesting at Moose Jaw in the summer of 1957 (Blue Jay, XV:147).

Previous records in or near the eastern half of the Qu-Appelle. Valley are as follows: George Lang reported taking two birds on May 24, 1890, and another on May 26, 1892, at Indian Head (H. H. Mitchell, 1924. Catalogue of the Birds of Saskatchewan) but these specimens are not extant. On May 26, 1929, a male remained most of the day about the Callin farm yard near Pervical and was twice observed by Elmer Callin at close range. On May 26, 1931, Fred Bárd took a specimen at Round Lake and listed the species as a probable nester there. Mr. Bard's specimen was the first established record for the province, adding a new species to the official list of Saskatchewan.

EDITOR'S NOTE: Mr. Callin may be interested to know that a Lazuli Bunting was observed earlier this year in Regina. A male bird was seen briefly in the Legislative Park on May 30, 1960, by Margaret Belchcr and George Leidingham. A second sparrow-coloured bird, glimpsed too briefly for positive identification, may have been the female. Neither bind was seen again. 